\title{
Okara Usage in Food Industry and Medical Application
}

\author{
Josephine Lai Chang Hui* and Rubiyah Baini \\ Department of Chemical Engineering and Energy Sustainability, Universiti Malaysia Sarawak (UNIMAS), Malaysia
}

Submission: May 01, 2018; Published: May 21, 2018

"Corresponding author: Josephine Lai Chang Hui, Department of Chemical Engineering and Energy Sustainability, Universiti Malaysia Sarawak (UNIMAS), Malaysia, Tel: +6082-581000; Fax: +6082-583409; Email: lchjosephine@unimas.my

\begin{abstract}
This mini review paper presented the applications of okara in two major fields namely food industry and medical fields. From the perspective of food industry, okara was introduced in food industry such as cookies, gluten free flour for baking purposes, extruded snack food with their optimal conditions. Okara modified with endopeptidase (Alcalase) and exopeptidase (Flavourzyme) improved the protein hydrolysis conditions. Endopeptidase with ultrasound pretreatment further improved the protein hydrolysates. Okara also improved the microbial activities to enhance nutritional quality and antioxidant activities to develop healthy animal feeds. From the perspective of medical application, okara became a potential agrowaste which applied as natural immobilizer due to prebiotics and probiotics fibers within okara. Prebiotics fiber helped in soymilk fermentation, glucosidic isoflavone bioconversion, cell resistance to simulated gastric and intestinal stresses as well as to enhance the human gut (faecal output) while probiotics fiber increased the protection against gastrointestinal juices. Okara also developed as dietary supplement that helped to prevent diabetes, obesity and hyperlipidemia.
\end{abstract}

Keywords: Okara; Applications; Food; Medical

\section{Introduction}

Soymilk and tofu consumption have been greatly increasing as it is claimed that both soymilk and tofu are good in improving cardiovascular health. In processing the soymilk or tofu, the byproducts namely okara was produced either in equal amount or more than the products produced. The continuous production of soymilk and tofu lead to serious disposal problem due to high moisture content within okara as well as short shelf life which limited the applications of okara in large scale operations. Therefore, okara was undergo intensive research to be applied in two major fields namely food industry and medical applications.

From the perspective of food industry, around $47-50 \%$ of okara provided optimal condition to produce okara based cookies preparation [1]. The incorporation of okara reduced the water absorption towards the cookies. However, the beany flavour affected the aroma and taste of the cookies. Another research showed that okara was blended with broken rice by undergoing single-screw extrusion to form extruded snack food [2]. The optimum conditions to achieve this snack food were the reduction of moisture content must be around $14-22 \%$ and the ratio of broken rice towards okara should be either $70-30$ or $90-10$. The barrel temperature must be maintained at $120-160{ }^{\circ} \mathrm{C}$ and the screw speed at 50 90rpm. The introduction of okara into the broken rice enhanced bulk density while reducing the sectional expansion index and specific length of the snack food. Another type of food products was gluten free flour which were produced by drying the okara incorporated okara with other ingredients for baking purposes [3]. This flour was suitable to be used by individuals who suffered from celiac disease. Besides, the flour produced can be used to improve the fiber and protein contents of food to replace wheat or soy flour in the production of biscuits, cookies, pancakes and muffins. Thus, this improved the value of okara. Okara modified with both endopeptidase (Alcalase) and exopeptidase (Flavourzyme) was proven to improve antioxidant activity of protein hydrolysates to obtain value-added peptides in Applications of Okara 2 a processing food products [4].

The same group of researchers further investigated and proven that okara could be well optimized using Alcalase endopeptidase through ultrasound pretreament which increased the protein hydrolysis conditions [5]. The optimum conditions obtained were enzymatic hydrolysis at $55^{\circ} \mathrm{C}, 8.8 \%$ of enzyme substrate ratio and $\mathrm{pH}$ 9.0. Besides food productions for human being, okara could be utilized in producing animal feed supplements [6]. The yeast fermented soybean curd residue (okara) reduced the fiber contents that was able to improve the microbial activities that enhanced the nutritional quality and antioxidant activities by lowering the fortification level in developing healthy animal feed supplements. Through this method, the cost of producing the healthy animal feed could be significantly reduced. 
Another perspective of improving the value of okara by applying in medical field. Okara was well functioned as prebiotic and probiotic fibers that improved the health conditions of human beings. Research of Xia, Wang, Liu, Li and Zhou (2016) presented that the food-grade byproduct named okara which was rich in prebiotics was functioned as natural immobilizer on few conditions namely soymilk fermentation, glucosidic isoflavone bioconversion, and cell resistance to simulated gastric and intestinal stresses [7].

Immobilized Lactobacillus plantarum cells provided higher specific growth rate with rapid decreasing in $\mathrm{pH}$ that protected the okara from spoilage. In addition, okara could be acted as potential immobilization carrier to improve cell survivability in gastric and intestinal conditions. Another group of researchers proven that treated okara via in vitro process was an alternative prebiotic from agrofood industrial waste which increased the soluble dietary fibre content to enhance the human gut [8]. The optimum conditions to produce a potential prebiotic effect of okara were 48 hours, pH-controlled and anaerobic batch cultures introduced with human faecal slurries. Moreover, the introduction of okara onto fermented soy products through in vitro method could be an important method that enhanced the probiotic protection against gastrointestinal juices as it did not affect the viability of Lactobacillus acidophilus La-5 and Bifidobacterium animalis Bb-12 within the product [9].

Okara was also prepared as dietary supplement which might prevent diabetes, obesity and hyperlipidemia [10]. This was clearly proven the research of [10] that the plasma levels of triglycerides as well as total cholesterol in Syrian hamsters were significantly decreased $20 \%$ by feeding okara supplemented diets that helped in faecal output [11]. The aim of this study is to review the applications of okara in food industry and medical fields. Through this review, the application of okara should be widen with optimal conditions.

\section{Discussion}

The by-product from soymilk and tofu processed produced soy residues namely okara. Okara contained high amount of fiber with low fat amount. These conditions led to the high utilization of okara in food industry as well as the medical field. However, okara contained high moisture and usually in wet conditions. This prevented okara from further utilized in wider scope. The optimum conditions obtained from previous research on okara in solid state food products was 47-50\%. Besides, moisture content of okara should be greatly reduced until $14-22 \%$. Based on the optimal conditions, okara was able to incorporate into other substances with the ratio to other substance of 1:1. This helped to reduce the disposal problem and increased the value of low-cost okara. Okara should undergo drying to obtain minimum amount of moisture. Many drying processes were available such as jet spouted bed of sorbent particles method [12], air jet impingement drying [13], convective drying [14], flash drying [15] and others. Therefore, with the aid of drying methods, solid okara or okara powder could be achieved with minimum moisture content. However, the nutritional quality of okara should be improved through drying processes. Thus, drying temperature should be around $55^{\circ} \mathrm{C}$ to enhance enzymatic hydrolysis with the $\mathrm{pH}$ of okara maintained at 9.0. With the introduction of immobilized Lactobacillus plantarum cells, okara could maintained the $\mathrm{pH}$ to prevent the spoilage of okara. Besides the immobilized Lactobacillus plantarum cells, yeast fermented okara could be applied to expand the microbial activities that boosted the nutritional quality and antioxidant activities.

With the optimal conditions achieved, okara is suggested to be applied as biofertilizers for agricultural plantation such as mushrooms as it contains high concentrations of organic nitrogen and phosphorus. However, the insolubility of okara as well as the high molecular weight of proteins and carbohydrates can prevent the application of okara. The introduction of either endopeptidase Applications of Okara 3 (Alcalase) or exopeptidase (Flavourzyme) improves antioxidant activity of protein hydrolysates within okara and thus, okara can be developed as biofertilizer in agricultural plantation and at the same time, the soil of plantation can be significantly improved.

\section{Conclusion}

Okara can be applied in two major fields namely food industry and medical fields. Both applications bring benefit to human beings and animals. In food industry, okara undergo various processes to achieve optimal conditions that improved the nutritional quality of the food. Besides, animal feed could be produced at low-cost as well as healthy to the animals been feed. In medical field, endopeptidase and exopeptidase increased the protein hydrolysates that improved the health conditions within human bodies. Okara was suggested to be applied not only as food, animal feeds, supplemented diets, it could be applied as biofertilizer for agricultural plantation especially mushroom which was agronomically, environmentally and sustainability for the ecosystem.

\section{Conflict of Interest}

The authors have no conflicts of interests to declare.

\section{References}

1. Ahmed H, Satheeshi N, Dibaba K (2018) Functional, physical and sensory properties of cookies prepared from okara, red teff and wheat flours. Croatian J Food Sci Tech 10(1): 1-10.

2. Varsha K, Mohan S (2016) Production of value added snacks from rice broken and okara by extrusion cooking technology. Int J Agricul Sci 8(51): 2321-2325.

3. Aguado A (2010) Development of okara powder as a gluten free alternative to all purpose flour for value added use in baked goods. University of Maryland, USA, pp. 1-88.

4. Sbroggio MF, Montilha MS, Figueiredo VRG, Georgetti SR, Kurozawa LE, et al. (2016) Influence of the degree of hydrolysis and type of enzyme on antioxidant activity of okara protein hydrolysates. Food Sci Tech 36(2): 375-381. 
5. Montilha MS, Sbroggio MF, Figueiredo VRG, Ida EI, Kurozawa LE, et al. (2017) Optimization of enzymatic protein hydrolysis conditions of okara with endopeptidase Alcalase. Int Food Res J 24(3): 1067-1074.

6. Rashad MM, Madmoud AE, Abdou HM, Nooman MU (2011) Improvement of nutritional quality and antioxidant activities of yeast fermented soybean curd residue. African J Biotech 10(28): 5504-5513.

7. Xia X, Wang Y, Liu X, Li Y, Zhou J, et al. (2016) Soymilk residue (okara) as a natural immobilization carrier for Lactobacillus plantarum cells enhances soymilk fermentation, glucosidic isoflavone bioconversion, and cell survival under simulated gastric and intestinal conditions. PeerJ 4: 1-19.

8. Perez-Lopez E, Cela D, Costabile A, Mateos-Aparicio I, Ruperez P, et al. (2016) In vitro fermentability and prebiotic potential of soyabean Okara by human faecal microbata. British J Nutri 116(6): 1116-1124.

9. Bedani R, Rossi EA, Saad SMI (2013) Impact of inulin and okara on Lactobacillus acidophilus La-5 and Bifidobacterium animalis Bb-12 viability in a fermented soy product and probiotic survival under in vitro simulated gastrointestinal conditions. Food Microbio 34: 382 389.
10. Li B, Qiao MY, Lu F (2011) Composition, nutrition and utilization of okara (soybean residue). Food Rev Int 28(3): 231-252.

11. Vilanueva MJ, Yokoyama WH, Hong YJ, Barttley GE, Ruperez P, et al. (2011) Effect of high0-fat diets supplemented with okara soybean byproduct on lipid profiles of plasma, liver and faeces in Syrian hamsters. Food Chem 124: 72-79.

12. Wachiraphansakul S, Devahastin S (2007) Drying kinetics and quality of okara dried in a jet spouted bed of sorbent particles. LWT-Food Sci Tech 40(2): 207-219.

13. Wang G, Deng Y, Xu X, He X, Zhao Y, et al. (2016) Optimization of air jet impingement drying of okara using response surface morphology. Food Control 59: 743-749.

14. Persussello CA, Amarante ACC (2009) Convective drying kinetics and darkening of okara. Drying Tech. 27(10): 1132-1141.

15. Grizotto RK, Aguirre JM (2011) Study of the flash drying of the residue from soymilk processing - okara. Food Sci Tech 31(3): 1-9.

\section{Your next submission with Juniper Publishers} will reach you the below assets

- Quality Editorial service

- Swift Peer Review

- Reprints availability

- E-prints Service

- Manuscript Podcast for convenient understanding

- Global attainment for your research

- Manuscript accessibility in different formats

( Pdf, E-pub, Full Text, Audio)

- Unceasing customer service

Track the below URL for one-step submission https://juniperpublishers.com/online-submission.php 